\title{
Petrophysical Properties of Khasib Formation in East Baghdad Oil Field Southern Area
}

\author{
Layth A. Jameel, Fadhil S. Kadhim and Hussein Ilaibi Al-Sudani
}

Petroleum Technology Department, University of Technology, Baghdad, Iraq

\begin{abstract}
Petrophysical properties evaluation from well log analysis has always been crucial for the identification and assessment of hydrocarbon bearing zones. East Baghdad field is located $10 \mathrm{~km}$ east of Baghdad city, where the southern area includes the two southern portions of the field, Khasib formation is the main reservoir of East Baghdad oil field.

In this paper, well log data of nine wells have been environmentally corrected, where the corrected data used to determine lithology, shale volume, porosity, and water saturation. Lithology identified by two methods; neutron-density and M-N matrix plots, while the shale volume estimated by single shale indicator and dual shale indicator, The porosity is calculated from the three common porosity $\operatorname{logs}$; density $\log$, neutron $\log$, and sonic $\log$, the water saturation is calculated by Indonesian model and Archie equation, and the results of the two methods were compared with the available core data to check the validity of the calculation.

The results show that the main lithology in the reservoir is limestone, shale volume ranged between 0.152 to 0.249 , porosity between 0.147 to 0.220 , and water saturation from 0.627 to 0.966 , the high-water saturation indicate that the water quantity is the determining factor of the reservoir units.
\end{abstract}

Keywords: petrophysical properties, well logs analysis, carbonate formation.

Received on 04/02/2020, Accepted on 21/09/2020, published on 30/12/2020

https://doi.org/10.31699/IJCPE.2020.4.5

\section{1- Introduction}

Carbonate reservoirs contain more than $60 \%$ of the world's oil reserves and contribute to more than $30 \%$ of the world's daily oil production. These carbonate reservoirs are more challenging when estimating the petrophysical properties and understanding the fluid flow mechanisms, compared to most sandstone reservoirs. Fluid flow through heterogeneous carbonate reservoirs is a very different and challenging process from the flow through homogeneous sandstone reservoir, as carbonate rocks tend to have a more complex pore system than sandstone [1], also the greater chemical reactivity of carbonate minerals, as carbonate rocks are mostly composed of calcite which is reactive to formation brine [2]. Formation evaluation is the process of interpreting a combination of measurements taken from inside the wellbore to evaluate wells for potential hydrocarbon bearing rocks, these measurements could be cores, laboratory measurements of fluid properties, and well logs. Well logs are considered one of the main sources of data for the geological and petrophysical parameters of reservoir formations; well logging plays a crucial role in the determination of the production potential of a hydrocarbon reservoir [3]. This study aims to determine the main petrophysical properties and lithology of Khasib formation in the east Baghdad southern area oil field. The field is newly under development and the study is aimed to give a better understanding of the reservoir characteristics to provide tools for future field economic feasible-development plans.

\subsection{Area of case study}

East Baghdad is a super-giant oil field located in Baghdad and Saladin governorates, $10 \mathrm{~km}$ east of Baghdad city. The contract area for the east Baghdad field covers the portion north-west of the Diyala River and is 65 kilometers long and 11 kilometers wide. East Baghdad holds 8 billion barrels proven reserves.

East Baghdad oil field is subdivided geographically into six areas, from northwest to southeast; respectively North Extension, Al-Taji, Al-Rashdiya, Urban, South 2, and South 1 areas [4]. East Baghdad's southern area includes both south 2 and south 1. Fig. 1 shows the location of the East Baghdad oil field on the Iraq oil location map. Khasib formation is the main reservoir of the east Baghdad oil field [5], it is bounded by Tanuma formation at the top and Kifil formation at the bottom. Khasib formation is subdivided into nine zones; $\mathrm{K} 1$ to $\mathrm{K} 9$, Based on the recognition of depositional cycles and lithological changes [6]. 


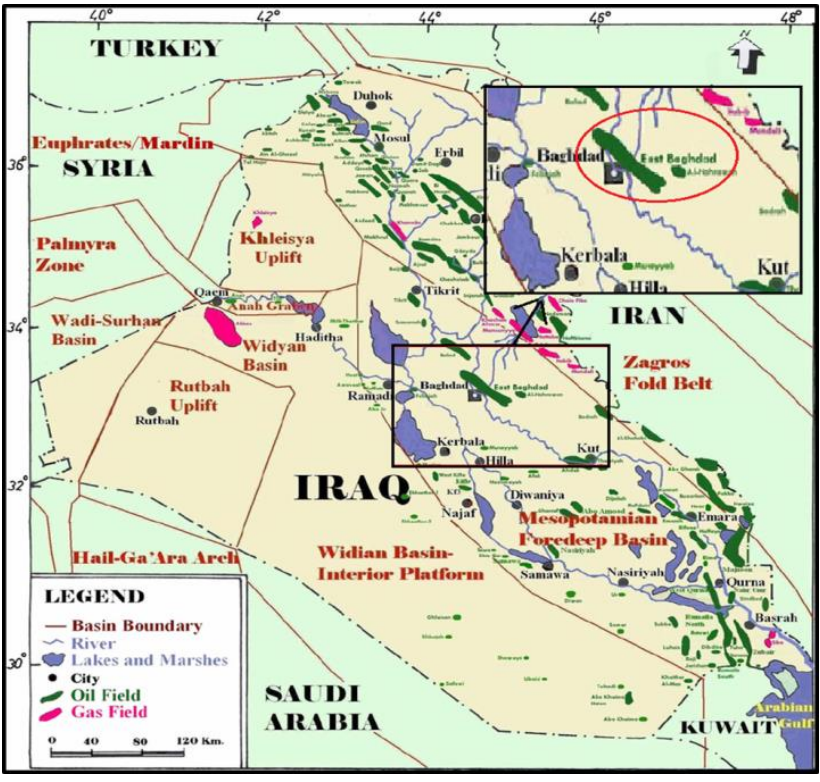

Fig. 1. Iraq oil location map [7]

\section{2- Methodology}

Interactive Petrophysics software (IP V3.5, 2009) has been used for correction and interpretation. Nine wells from the east Baghdad southern area have been used in this study, as provided by the reservoir department/ministry of oil. The wells are EB4, EB5, EB15, EB18, EB26, EB30, EB38, EB48, and EB54, all these wells are exploration wells, no production wells have been drilled before in this field. The data were used from available well log records in form of LAS-files; such as potential spontaneous records (SP), gamma rays, density, sonic, neutrons, and resistivity. The workflow diagram is shown in Fig. 2.

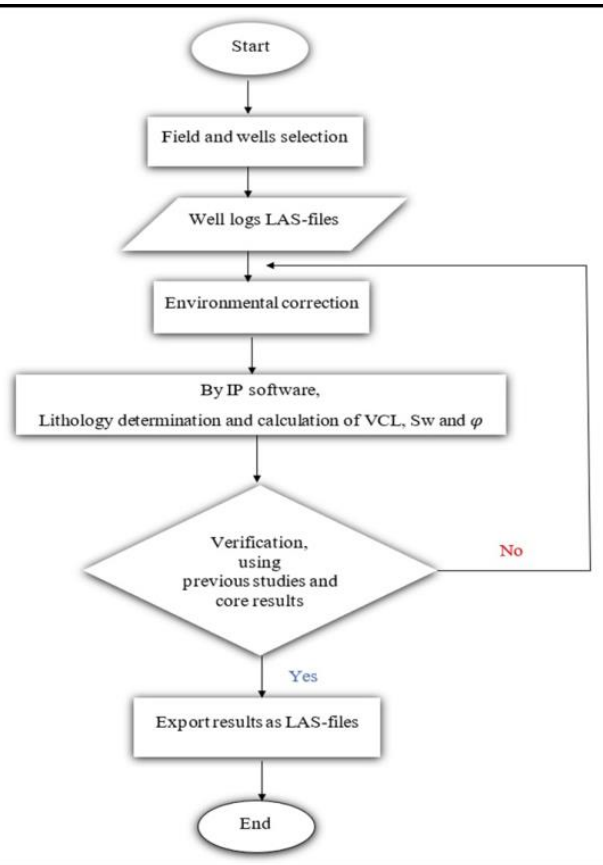

Fig. 2. Well logs interpretations methodology flow diagram

\section{3- Results and Discussion}

\subsection{Environmental Correction}

The environmental corrections were carried out by the environment correction module provided by Interactive Petrophysics (IP v4.2) software. As shown in Fig. 3, Schlumberger Log Interpretation Charts (2000 Edition) has been used as the well log data are provided by Schlumberger oilfield services company. The results show a noticeable increase in gamma-ray readings, Gamma-ray is corrected to mud properties (mud type and weight) and borehole condition, while the borehole has no cavities as caliper log shows, then the mud properties were the determining factor in this change. Induction resistivity shows no change between readings which indicates that the raw logs readings were not affected by drilling mud in the invention zone.

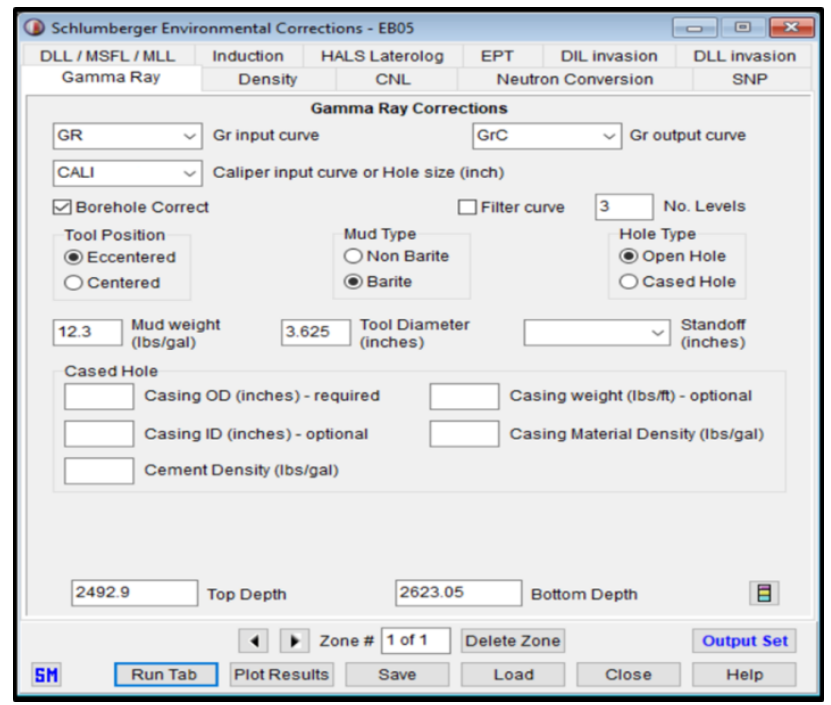

Fig. 3. Schlumberger environmental correction window from IP software

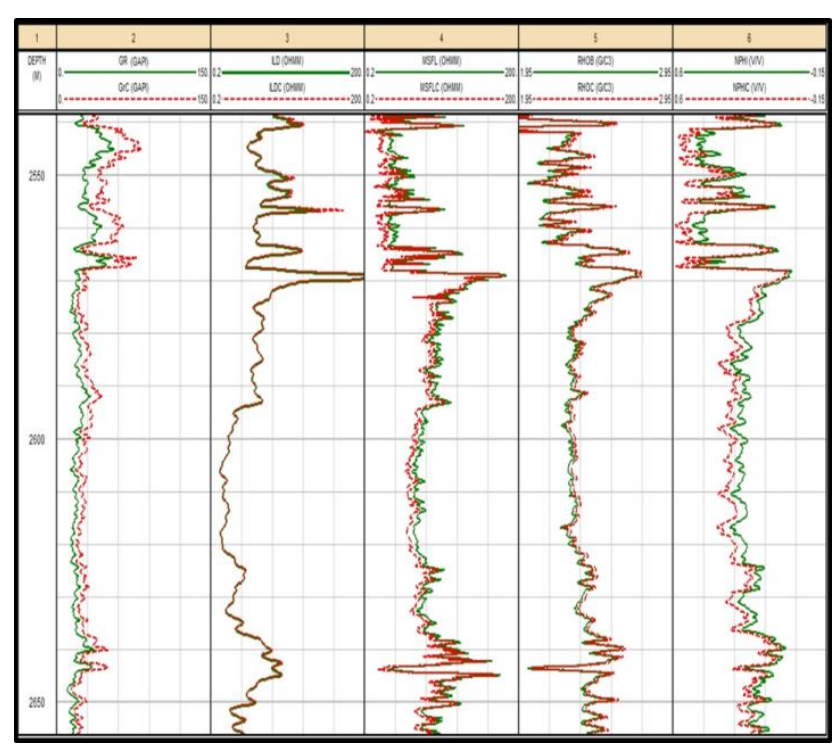

Fig. 4. Environmental correction log plot of EB30 (generated by IP software) 
Micro resistivity $\log$ and density $\log$ show a minor change in their readings due to drilling mud and the logging used tools.

Neutron density shows clear shifting between the readings, the corrected readings were increased; neutron $\log$ is affected by many parameters such as drilling mud and formation proprieties and lithology.

Fig. 4 shows a log plot of the corrections of well EB30, the green solid lines represent the logs reading while the red dot lines represent the corrected reading.

\subsection{Lithology Identification}

The concept behind lithology identification is the distinct responses porosity logs show to different types of minerals. Any combination of the three porosities logs (density, neutron, and sonic logs) can give an appropriate indication of the formation lithology [8].

Density-neutron plot is a cross plot with neutron log readings on the $\mathrm{x}$-axis versus density log readings on the $y$-axis, whereby the use of gamma-ray ranges- the mineral type is presented and clearly shown.

Fig. 5 shows the Density-neutron plot of well EB18, the results show that the dominant mineral matrix in the formation is limestone; this result is compatible with the geological reports of the wells which identify Khasib formation as limestone porous. M-N plot is generated from the interpretations of density, neutron, and sonic logs. $\mathrm{M}$ and $\mathrm{N}$ are lithology dependent parameters.

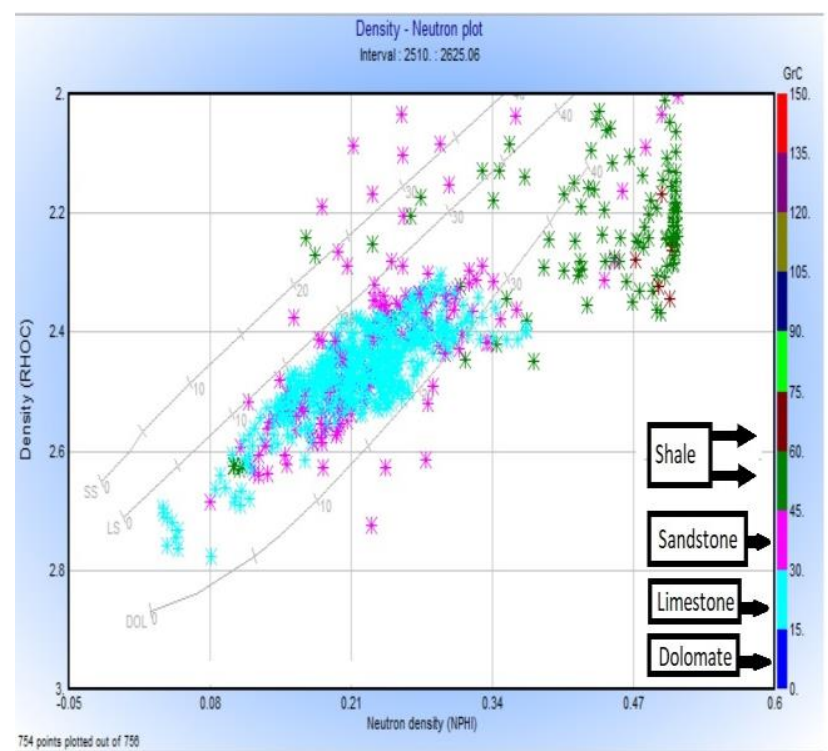

Fig. 5. Density - neutron lithology cross plot of EB18 (generated by IP software)

Fig. 6 shows the M-N plot of well EB18. M-N plot illustrates that the formation consists of limestone, as the major accumulation of the points is in the carbonate zone.
Also, it can be seen that no reasonable secondary porosity in the formation, and there is no need to consider the secondary porosity when evaluating the formation porosity. Due to these results, limestone parameters have been used -when needed- with other formation calculations.

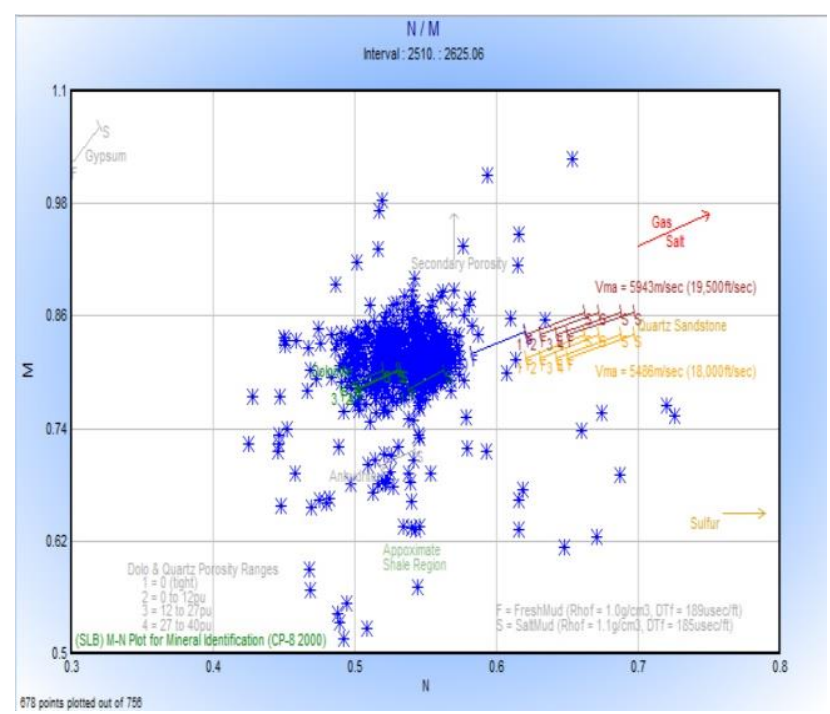

Fig. 6. M-N lithology cross plot of EB18 (generated by IP software)

\subsection{Shale Volume Calculation}

One of the most controversial issues in the formation evaluation is the shale effect on the rocks of the reservoir. Shale is usually more radioactive than sand or carbonate. Therefore, gamma-ray log and other logs can be used to calculate the volume of shale in a porous medium [9].

Three different shale indicators were used to estimate shale volume; gamma-ray, SP, and neutron-density. For each indicator a result shale volume was obtained; $V_{C L}$ from the gamma-ray log, $V_{L C}$ from SP $\log$ and VCL $\mathrm{VL}_{\mathrm{ND}}$ from neutron-density logs.

To avoid logging tools high readings errors, minimum shale volume (VCL) represents the target result from shale volume calculations, by which, shale volume of the formation was presented, as VCL represents the minimum shale response of all used indicators [10].

Fig. 7 shows an example of shale volume results curves; each tool curve track is followed by a shale curve interpreted from it, while the last track shows the minimum shale volume as it represents the result of all the indicators combined.

The results show a noticeable variation in shale volume through the wells tracks, which explain the division of the formation into nine zones, these zones are presented for well EB04 in figure 5 and can be seen in the second track. The average shale volume for each well is presented in the Table 1. 


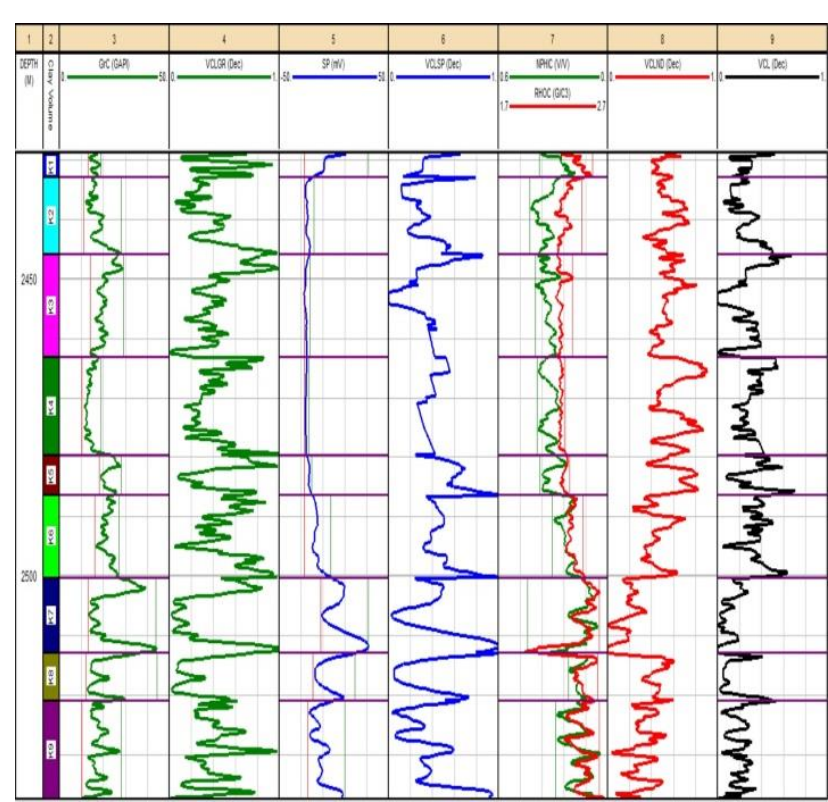

Fig. 7. Shale volume log plot of EB04 (generated by IP software)

Table 1. All wells Shale volume results as interpreted from well logs

\begin{tabular}{lll}
\hline Well & Well interval, $\mathrm{m}$ & Shale volume (VCL) \\
\hline EB04 & $2429-2537$ & 0.249 \\
EB05 & $2493-2623$ & 0.183 \\
EB15 & $2547-2661$ & 0.162 \\
EB18 & $2510-2625$ & 0.209 \\
EB26 & $2440-2550$ & 0.221 \\
EB30 & $2539-2656$ & 0.163 \\
EB38 & $2425-2522$ & 0.152 \\
EB48 & $2494-2607$ & 0.152 \\
EB54 & 2459.2574 & 0.197 \\
\hline
\end{tabular}

\subsection{Porosity Estimation}

Porosity is one of the most important reservoir properties as it represents the potential storage volume for hydrocarbons. In carbonate reservoirs, the porosity values range from $1 \%$ to $35 \%$ [11]. Porosity is measured either from core samples in the laboratory or from porosity well logs interpretations [12]. In this study, porosity was calculated from the three porosity logs (density, neutron, and sonic). Also, effective porosity was calculated by excluding the volume of shale from the total porosity.

Fig. 8 shows an example of porosity results, density porosity (PhiDen), neutron porosity (PhiNeu), and sonic porosity (PhiSon) is shown in tracks 2, 3, and 4 in a row, while the last track shows the effective porosity (PHIE).

The validation of the results is checked by comparing the predicted effective porosity with core porosity [13]. Table 2 illustrates effective porosity interrupted from well logs and porosity of core samples for the cored intervals as available in this study-. To present the prediction accuracy, the absolute percent error is calculated as follows:

$A P E=\left|\frac{P H I_{\text {log }}-P H I_{\text {core }}}{P H I_{\text {core }}}\right| \times 100 \%$
Where, $\mathrm{PHI}_{\text {log }}$ is predicted porosity and $\mathrm{PHI}_{\text {core }}$ is core samples porosity.

The results of the absolute percentage error ranged from 1.07 to 6.63 percent. Correlation between log porosity and core porosity has been made to gain more accurate results; where the correlation coefficient $\left(\mathrm{R}^{2}\right)$ of this correlation equals 0.856563. Equation (2) is the correction equation generated from statistical analysis as shown in Fig. 9.

$$
P H I_{\text {log }}=-0.02667853+\left(1.080926228 \times P H I_{\text {core }}\right)
$$

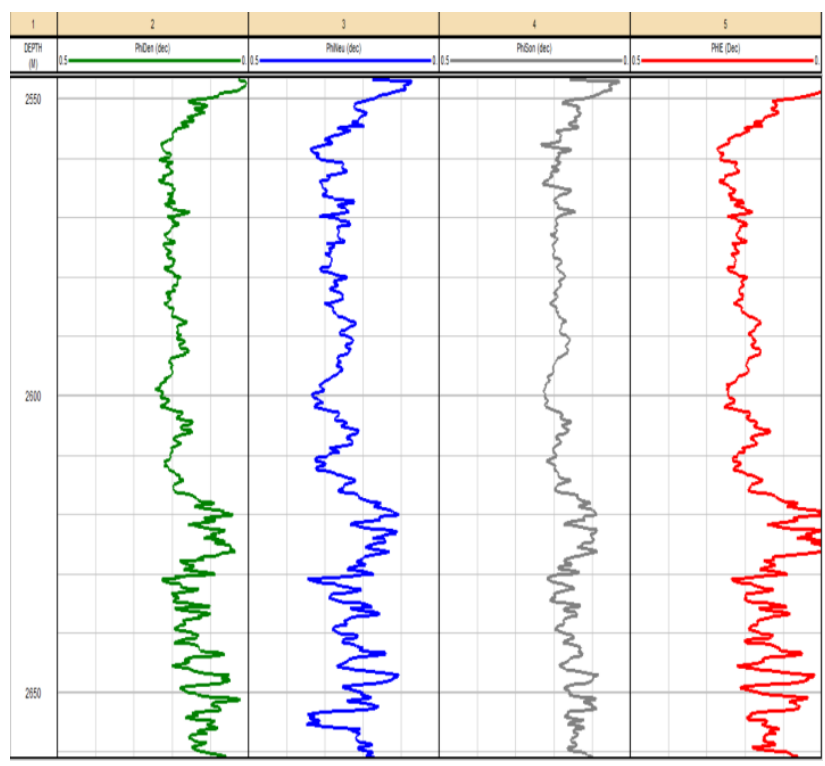

Fig. 8. Porosity results log plot of EB15 (generated by IP software)

Table 2. Comparison of $\log$ porosity versus core porosity for available cored wells

\begin{tabular}{lllll}
\hline Well & Interval, $\mathrm{m}$ & Log porosity & Core porosity & APE \% \\
\hline EB04 & $2429-2470$ & 0.264 & 0.258 & 2.32 \\
EB05 & $2498-2533$ & 0.189 & 0.187 & 1.07 \\
EB26 & $2443-2478$ & 0.235 & 0.238 & 1.26 \\
EB30 & $2541-2578$ & 0.169 & 0.181 & 6.63 \\
\hline
\end{tabular}

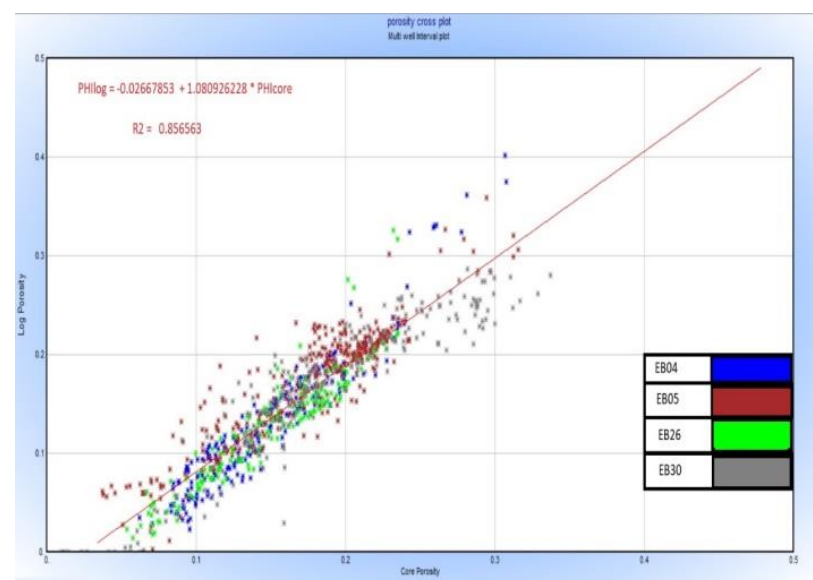

Fig. 9. Core porosity versus log porosity cross plot (generated by IP software) 
The predicted porosity is corrected by equation (3), which was produced by simple manipulation to equation (2); by solving the equation to $\mathrm{PHI}_{\text {core }}$ and consider it as the corrected porosity $\left(\mathrm{PHI}_{\mathrm{C}}\right)$.

$P H I_{C}=\frac{P H I_{l o g}+0.02667853}{1.080926228}$

From the corrected porosity, average porosity has been calculated for each well understudy, as illustrated in Table 3. The results show a variation of porosity between wells due to formation heterogeneity, the porosity ranged from 0.220 to 0.147 .

Table 3. All wells Porosity results as interpreted from well logs

\begin{tabular}{lll}
\hline Well & Well interval, $\mathrm{m}$ & porosity \\
\hline EB04 & $2429-2537$ & 0.209 \\
EB05 & $2493-2623$ & 0.192 \\
EB15 & $2547-2661$ & 0.198 \\
EB18 & $2510-2625$ & 0.176 \\
EB26 & $2440-2550$ & 0.213 \\
EB30 & $2539-2656$ & 0.214 \\
EB38 & $2425-2522$ & 0.176 \\
EB48 & $2494-2607$ & 0.220 \\
EB54 & 2459.2574 & 0.147 \\
\hline
\end{tabular}

\subsection{Water Saturation Calculations}

Water saturation is one of the most important petrophysical parameters information evaluation. Water saturation is used to estimate oil in place, perforation zones detection also depends mainly on the knowledge of water saturation in the formations [14].

Empirical methods are used to calculate water saturation from well logs, depending mainly on resistivity measurements. Indonesian model and the Archie equation are two of the most used methods for the calculations [15].

Fig. 10 shows Pickett's plot for well EB48, In the figure, the red line represents $100 \%$ water saturation, while the three blue lines represent the water saturation of $50 \%, 30 \%$, and $20 \%$ depending on its distance from the red line (closest is the highest).

The slope value of the $100 \%$ water saturation line is the cementation factor. Table 4 illustrates the values of ( $\mathrm{Rw}$, $\mathrm{m}, \mathrm{n}$, and a) for each well in this study.

A log plot example of water saturation results from Archie and Indonesian methods is shown in Fig. 11; water saturation obtained from Archie method (SwArch) is presented in the second track, while the third track shows the result of Indonesian method (Swind), also water saturation of core plug samples (SWcore) is shown in both of the tracks by red dots.

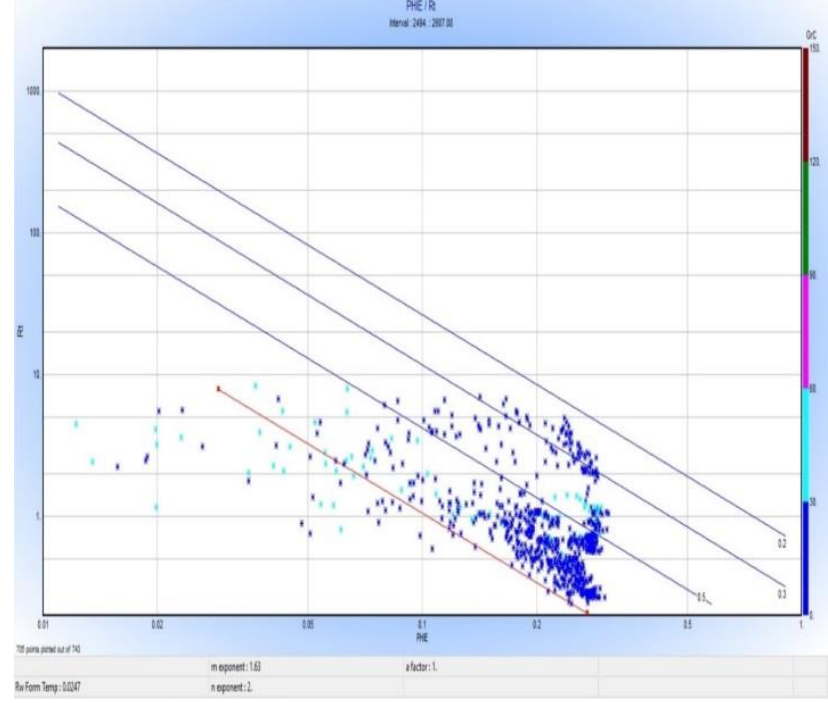

Fig. 10. Pickett's plot of EB48 (generated by IP software)

Table 4. All wells Archie parameters

$\begin{array}{lllll}\text { Well } & \text { Rw } & \mathrm{m} & \mathrm{n} & \mathrm{a} \\ \text { EB04 } & 0.0255 & 1.8 & 2 & 1 \\ \text { EB05 } & 0.0268 & 1.9 & 2 & 1 \\ \text { EB15 } & 0.0250 & 1.8 & 2 & 1 \\ \text { EB18 } & 0.0371 & 1.52 & 2 & 1 \\ \text { EB26 } & 0.0259 & 1.83 & 2 & 1 \\ \text { EB30 } & 0.0224 & 1.73 & 2 & 1 \\ \text { EB38 } & 0.0305 & 1.48 & 2 & 1 \\ \text { EB48 } & 0.0247 & 1.63 & 2 & 1 \\ \text { EB54 } & 0.0427 & 1.44 & 2 & 1\end{array}$

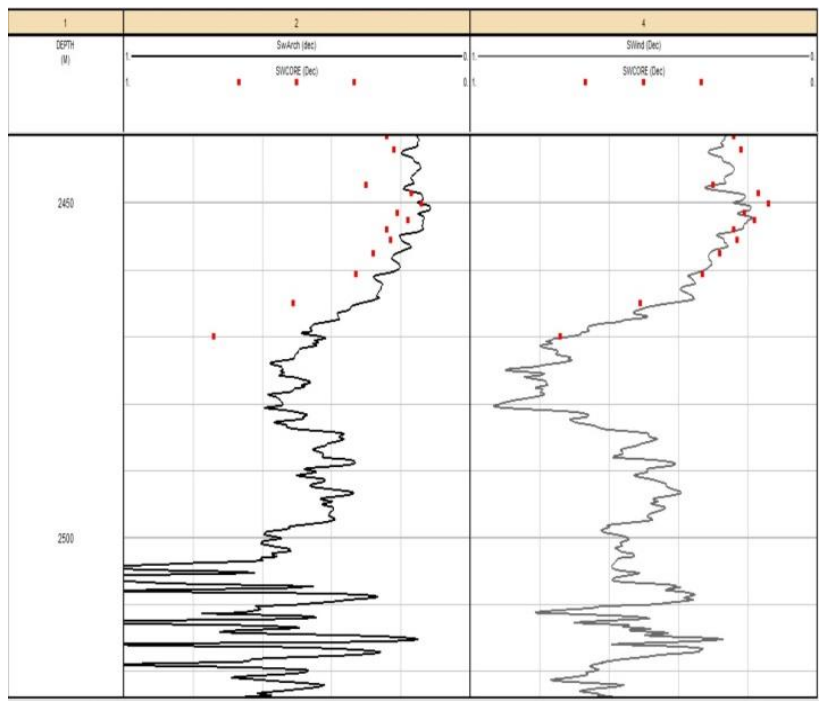

Fig. 11. Water saturation log plot of EB26 (generated by IP software)

Table 5 shows a comparison of average water saturation from Archie and Indonesian methods with water saturation measured from core samples. To determine the most accurate method, the absolute percentage error is calculated. The results of the Indonesian method are closer to core water saturation with APE ranged from 0.9 to 9.2 percent, while Archie shows a large lack of accuracy with errors ranged from 7.2 to 33 percent. 
The main reason behind Archie's method's poor results is that the formation contains relatively high shale volume, as well as the presence of pyrite in the invaded zone, as pyrite was used in the drilling mud. Shale and pyrite are conductive minerals which is one of Archie method limitations [16]. Indonesian method on the other hand was successful because it had been derived originally to study water saturation in a carbonate reservoir.

Table 5. Comparison of SwArch and Swind with Swcore for available cored wells

\begin{tabular}{lllllll}
\hline Well & Interval, $m$ & Swcore & SwArch & APE & Swind & APE \\
\hline EB05 & $2540-2550$ & 0.39 & 0.362 & 7.2 & 0.414 & 6.1 \\
EB26 & $2440-2470$ & 0.292 & 0.326 & 11.6 & 0.319 & 9.2 \\
EB30 & $2572-2597.6$ & 0.597 & 0.671 & 12.3 & 0.548 & 8.2 \\
EB38 & $2387.5-2457$ & 0.555 & 0.5 & 9.9 & 0.54 & 2.7 \\
EB48 & $2496.5-2510$ & 0.477 & 0.32 & 33 & 0.497 & 4.2 \\
EB54 & $2524-2548$ & 0.428 & 0.309 & 27.8 & 0.432 & 0.9 \\
\hline
\end{tabular}

Table 6 illustrates the average water saturation of all wells. The results show a maximum water saturation of $96.6 \%$ in well EB15, while the minimum percent is in well EB04 with $62.7 \%$ of water saturation; these results indicate that the formation primarily fluid is water.

Table 6. All wells water saturation results as interpreted from well logs

\begin{tabular}{lll}
\hline Well & Well interval, $\mathrm{m}$ & Water saturation \\
\hline EB04 & $2429-2537$ & 0.627 \\
EB05 & $2493-2623$ & 0.692 \\
EB15 & $2547-2661$ & 0.966 \\
EB18 & $2510-2625$ & 0.777 \\
EB26 & $2440-2550$ & 0.633 \\
EB30 & $2539-2656$ & 0.796 \\
EB38 & $2425-2522$ & 0.740 \\
EB48 & $2494-2607$ & 0.854 \\
EB54 & 2459.2574 & 0.787 \\
\hline
\end{tabular}

\section{4- Conclusions}

Petrophysical analysis has been carried out for reservoir characterization of Khasib formation in east Baghdad southern area oil fields, using a suite of well log data from nine wells in the field.

Lithological interpretation determines the main lithology of the formation as limestone, Porosity ranged from 0.147 to 0.220 , which is the normal ranges of carbonate reservoirs and water saturation ranged from 0.627 to 0.966 .

The high-water saturation and its variation through depth and well locations make it the determining factor to identify the pay zones.
Computer Processed Interpretation (CPI) of the wells indicates that the pay zones of the reservoir are the upper zones (upper Khasib), these zones contain the lowest water saturations, around $50 \%$, unlike the lower zones where water saturations exceed $90 \%$. Many wells show a high-water saturation at all the reservoir zones, which means that these wells are drilled in all water portions of the reservoir, these portions should be avoided in future field developments.

\section{Nomenclature}

$\begin{array}{ll}\text { APE: } & \text { Absolute percentage error } \\ \text { a: } & \text { Tortuosity factor } \\ \text { GR: } & \text { Gamma-ray } \\ \text { m: } & \text { Cementation factor } \\ \text { n: } & \text { Saturation exponent. } \\ \text { PHI: } & \text { Porosity } \\ \text { SP: } & \text { Spontaneous potential } \\ \text { Sw: } & \text { Water saturation } \\ \text { VLC: } & \text { Shale volume }\end{array}$

\section{References}

[1] N. Hurley, "Quantification of Vuggy Porosity in a Dolomite Reservoir from Borehole Images and Core, Dagger Draw Field, New Mexico," in Annual Technical Conference and Exhibition, New Orleans, Louisiana, 1998.

[2] S. Ehrenberg and P. H. Nadeau, "Sandstone vs. carbonate petroleum reservoirs: A global perspective on porosity-depth and porosity-permeability relationships," AAPG Bulletin, vol. 89, no. 4, pp. 435445, 2005.

[3] F. Aminzadeh and S. N. Dasgupta, "Geophysics in Drilling." In Developments in Petroleum Science, vol. 60, pp. 223-246. Elsevier, 2013.

[4] MDOC official web site," [Online]. Retrieved from http://www.mdoc.oil.gov.iq

[5] M. S. Al-Jawad and K. A. Kareem, "Geological Model of Khasib Reservoir- Central Area/East Baghdad Field," Iraqi Journal of Chemical and Petroleum Engineering, vol. 17, no. 3, pp. 1-10, 2016.

[6] B. Al-Qayim, F. Al-Saadoni, and a. Al-Biaty, "Diagenetic Evolution of The Khasib Formation EastBaghdad Oil Field," Iraqi Geological Journal, pp. 56$\underline{72,1993 .}$

[7] T. K. Al-Ameri and R. Y. Al-Obaydi, "Cretaceous petroleum system of the Khasib and Tannuma oil reservoir, East Baghdad oil field, Iraq," Arab J Geosci, $\underline{2011 .}$

[8] C. Dawei, Y. Xuanjun, Z. Chuanmin, T. Cong and W. Mengshi, "Logging-lithology identification methods and their application: A case study on," CHINA PETROLEUM EXPLORATION, 2016.

[9] G. Asquith and D. Krygowski, Basic Well Log Analysis, 2nd ed., AAPG, 2006. 
[10] E. Frost Jr, "Method for estimation of bulk shale volume in a real-time logging-while-drilling environment". United States of America Patent US 9,551,213 B2, 24 Jan 2017.

[11] F. J. Lucia, Carbonate reservoir characterization: An integrated approach. Springer Science \& Business Media, 2007.

[12] GB Asquith, D Krygowski, CR Gibson, Basic well $\log$ analysis. Vol. 16. Tulsa: American Association of Petroleum Geologists, 2004.

[13] Smith, M. M, Hao, Yue, Spangler, L. H, Lammers, Kristin, Carroll and S. A, "Validation of a reactive transport model for predicting changes in porosity and permeability in carbonate core samples," International Journal of Greenhouse Gas Control, vol. 90, p. 102797, 2019.

[14] J.-R. Ursin and A. B. Zolotukhin, "Fundamentals of petroleum reservoir engineering." (1997).

[15] L. M. Entyre, "Comparative Performance of a Dual Water Model Equation in Laminar Shaly Sands," 1993.

[16] Yu, Hongyan, Wei, Xiaolong, Wang, Zhenliang, Rezaee, Reza, Zhang, Yihuai, Lebedev, Maxim, Iglauer, Stefan and others, "Review of Water Saturation Calculation Methods in Shale Gas Reservoir," in SPE Asia Pacific Oil and Gas Conference and Exhibition, 2018. 


\title{
الخواص البتروفيزيائية لتكوين الخصيب في حقل شرق بغداد المنطقة الجنوبية
}

\author{
ليث عبد المالك جميل ، فاضل سرحان كاظم و حسين لعيبي السوداني
}

قسم تكنلوجيا النفط ، الجامعة النكنلوجية ، بغداد ، العراق

الخلاصة

يعتبر تحليل سجل الآبار وتقييم الخواص البتروفيزيائية خطوة اساسية لتحديد وتقييم المناطق الحاملة للهيدروكربونات. يقع حقل شرق بغداد على بعد 10 كم شرق مدينة بغداد ، حيث تضم المنطقة الجنوبية الجزأين الجنوبيين من الحقل ، ويعتبر تكوين الخصيب المكمن الرئيسي لحقل شرق بغداد النفطي. في هذه البحث ، تم اجراء التصحيحات البيئية لبيانات سجل الآبار والتي تشمل بيانات تسعة آبار من الحقل. استخدمت البيانات المصححة لتحديد ليثولوجيا التكوين وكمية الطفل والمسامية وتشبع الماء. تم تحديد الليثولوجيا بطريقتين: رسم (أم-أن) ورسم سجل الكثافة مقابل سجل النيوترون. في حين تم احتساب حجم الطفل بالمؤشرات الاحادية والمزدوجة ، والمسامية من خلال سجلات المسامية الثلاثة: سجل الكثافة وسجل النيوترون وسجل الصوتية. اما تتبع الماء فتم حسابه بالموديل الاندونيسي وبمعادلة آرتشي ، وتمت مقارنة نتائج الطربقتين بالبيانات المستخرجة من تحليل اللباب المتاحة لتحديد الطريقة الاكثز دقة. تنير النتائج إلى أن التكوين الصخري الرئيسي في المكمن هو الحجر الجيري ، وتراوح حجم الطفل بين 0.152 الى 0.249 والمسامية بين 0.147 إلى 0.220 وتتبع الماء بين 0.627 إلى لـ 0.966 إنى ان معدلات التشبع المائي العالية تبين ان قراءة تشبع الماء هو العامل البتروفيزيائي الاساسي لتحديد الوحدات المكمنية الرئيسية للتكوين.

الكلمات الدالة: خواص بتروفيزيائية ، تفسير مجسات الابار ، تكوينات كاربونية 